\title{
The Impact of Climate Change Adaptation Strategies on Income and Food Security: Empirical Evidence from Small-Scale Fishers in Indonesia
}

\author{
Moh. Shadiqur Rahman ${ }^{1}\left(\mathbb{D}\right.$, Hery Toiba $^{2, *}$ and Wen-Chi Huang ${ }^{3, *}$ (D) \\ 1 Department of Tropical Agriculture and International Cooperation, National Pingtung University of Science \\ and Technology, Pingtung 912, Taiwan; mohsodiqurrahman@gmail.com \\ 2 Agriculture Socio-Economic Department, Faculty of Agriculture, Brawijaya University, \\ Malang 65145, Indonesia \\ 3 Department of Agribusiness Management, National Pingtung University of Science and Technology, \\ Pingtung 912, Taiwan \\ * Correspondence: htoiba@ub.ac.id (H.T.); wenchi@mail.npust.edu.tw (W.-C.H.)
}

Citation: Rahman, M.S.; Toiba, H.; Huang, W.-C. The Impact of Climate Change Adaptation Strategies on Income and Food Security: Empirical Evidence from Small-Scale Fishers in Indonesia. Sustainability 2021, 13, 7905. https://doi.org/10.3390/ su13147905

Academic Editor: Gideon Baffoe

Received: 26 April 2021

Accepted: 12 July 2021

Published: 15 July 2021

Publisher's Note: MDPI stays neutral with regard to jurisdictional claims in published maps and institutional affiliations.

Copyright: (c) 2021 by the authors. Licensee MDPI, Basel, Switzerland. This article is an open access article distributed under the terms and conditions of the Creative Commons Attribution (CC BY) license (https:// creativecommons.org/licenses/by/ $4.0 /)$.

\begin{abstract}
The impacts of climate change on marine capture fisheries have been observed in several studies. It is likely to have a substantial effect on fishers' income and food security. This study aims to estimate the impact of adaptation strategies on fishers' income and their household's food security. Data were collected from small-scale fishers' households, which own a fishing boat smaller or equal to five gross tonnages (GT). The study sites were the two coastal regions of Malang and Probolinggo in East Java, Indonesia, due to the meager socioeconomic resources caused by climate change. A probit regression model was used to determine the factors influencing the fishers' adaptation. Propensity score matching (PSM) was applied to evaluate the impact of the adaptation strategies on income and food security. Food security was measured by food consumption score (FCS). The findings indicated that participation in the fishers' group affected adaptation strategies significantly, and so did the access to credit and climate information. Also, PSM showed that the adaptation strategies had a positive and significant impact on fishers' income and food security. Those who applied the adaptation strategies had a higher income and FCS than those who did not. This finding implies that the fishery sector's adaptation strategies can have significant expansion outcome and reduce exposure to risks posed by climate change. Therefore, the arrangement of more climate change adaptation strategies should be promoted by the government for small-scale fishers in Indonesia.
\end{abstract}

Keywords: capture fisheries; East Java; food consumption score; probit regression; propensity score matching

\section{Introduction}

Climate change is a global phenomenon that affects the natural environment, with temperature change becoming the most immediate indicator. International studies have documented that climate change has affected countries around the world, including in Indonesia. This country has experienced climate change phenomena to a large extent. Climate change in Indonesia can be seen by changes in climate variability. For instance, a study conducted by Aldrian and Djamil [1] showed that, between 1991 and 2005, the average annual rainfall in Indonesia reached $2300 \mathrm{~mm}$. Using rainfall data from 1981 to 2016, Avia [2] claimed that the annual rainfall in Indonesia had significantly changed, especially in several provinces of Java islands including East Java, Central Java, Jakarta, and West Java. As the country with the third-longest coastline in the world [3], Indonesia's capture fishery is highly vulnerable to this phenomenon, due to the effect of climate change on ocean conditions. A change of a few degrees in ocean temperature can cause a major hydrologic change that affects the biological, physical, and chemical conditions of the ocean [4]. 
Theoretically, climate change will affect the fishery sector in three ways. First, climate change shifts the physical and chemical conditions, such as increasing water temperature, sea level, and stratification, as well as reducing dissolved oxygen and ocean acidification. Second, climate change affects the biological conditions of the ocean such as diseases, and changes in species distribution and species abundance. Third, it impacts the socioeconomic condition, such as disrupted fishing activities and reduced fishing productivity [5]. Grafton [6] claimed that climate change alters species, changing the distribution and mix of species that will have a rippled effect on marine and fisheries ecosystems. Using projection models to examine changes in future distributions, Kleisner, et al. [7] projected that many local species are expected to have a large reduction in the northeast of the United States due to increasing ocean temperature. Some organisms may respond to climate change by moving to more favorable regions or by adjusting their productivity in response to new circumstances in certain areas. A study conducted by Asante and Amuakwa-Mensah [8] found that climate variables such as temperature and participation significantly affect capture fisheries' production and total annual catchment. It is becoming increasingly indisputable that climate change will reduce fisheries' productivity in the coming years $[9,10]$.

The impact of climate change on fisheries' actors has been increasingly evident, especially among small-scale fishers. According to Daw, et al. [11] and Grafton [6], small-scale fishers are highly vulnerable to climate phenomena because they depend on natural resources as the primary source of their income. Furthermore, small-scale fishers with limited access to fishing ground areas are likely to be the most sensitive to climate phenomena [6]. Colgan and Merrill [12] illustrated how unpredictable weather could disrupt fishers' daily socioeconomic activities and reduce their working days. Likewise, previous studies have reported that changes in rainfall intensity, and increased winds and floods have posed threats and uncertainty among small-scale fishers as these rapid changes impact the fish catchability [13]. Concern about climate change being disadvantageous to the income of small-scale fishers, therefore, is growing.

This is worrying, as the role of marine fisheries in food security is crucial. It is an important source of food supply and fish is a major source of protein in people's diets, which can enrich nutrient intake even by the smallest amount of consumption [14]. Worldwide, fisheries contribute to one billion people's livelihood and the quality of diet among the fishers' communities, as it is the highest source of protein [15]. Fisheries can also indirectly assist food security; for instance, by providing revenue for the small-scale fishers, hence increasing their purchasing power [16]. However, the effects of climate change on the productivity of small-scale fishers are threatening their food security [17].

To mitigate the negative impact of climate change, small-scale fishers need to adopt adaptation strategies, and this is becoming an important component in the fishery sector. Adaptation to climate change among fisheries can be applied on different levelsindividual, regional, sectoral, national, and global [18]. On an individual level, small-scale fishers (Based on Fisheries Law of Indonesia No. 45/2009, small-scale fishers on an individual level are fishers who capture the fish to fulfill their daily needs, with a fishing boat smaller or equal to five gross tonnages (GT)) probably find it the most difficult to apply [19]. A number of studies have been conducted in an attempt to improve fishers' adaptation strategies, i.e., by investigating the factors influencing climate change adaptation. For instance, Abu Samah, et al. [20] investigated the effect of the socio-demographic characteristic of small-scale fishers on climate change adaptation. The findings indicated that the adaptation was significantly affected by the fishing experience, age, and income. However, the household size did not significantly affect the adaptation strategy. Another study was conducted by Sereenonchai and Arunrat [21] to examine the factors affecting fishers' decision to adopt climate change adaptation. Using binary logistic regression, they found that fishers' decision to adopt climate change adaptation was positively affected by the fishing experience, institutional access, and income. Employing the theory of planned behavior to investigate factors associated with fishers' adaptation intentions, 
Lowe, et al. [22] summarized that fishers with non-fishing income were more likely to adapt to climate change by declining fishing pressure, improving income, and receiving assistance from friends and family. Furthermore, Le Dang, et al. [23] assessed the impact of psychological factors on adaptation intention using a protection motivation theory. The finding revealed that the perceived risk of climate change and the adaptive measures have a positive effect on adaptation intention. However, rejection of the climate change risk and maladaptation (i.e., fatalism and wishful thinking) negatively impacts the adaptation intention.

Although the previous studies on climate change and fishery sectors have been internationally documented, most of them only looked into the impact of climate change on ecosystems [24,25], fishery productivity $[19,26]$, and food security $[16,27,28]$. Research has also suggested the adaptation strategies and factors affecting the adaptation strategies $[20,21]$. Empirical evidence is not sufficient to demonstrate the impact of adaptations on the fishers' income and food security. To fill this gap, this study aims to examine factors that influence fishers' adaptation strategies and their impact on income and household food security. Therefore, to answer the main objective of this study, two critical questions should be answered: first, what are the factors that influence fishers' decision to adopt the adaptation strategies? Second, what is the impact of climate change adaptation strategies on fishers' income and food security?

\section{Literature Review}

\subsection{Climate Change and Small-Scale Fisher}

Small-scale fishers are vulnerable to climate phenomena because they depend on marine resources to fulfill their livelihood needs. In addition, geographical location and economic conditions also cause small-scale fishers to be highly vulnerable to climate change. As a fishing community located in a coastal area, fishers are more easily exposed to the climate change phenomena such as hurricanes, cyclones, rising sea levels, sea acidification, inundations, and coastal erosion [29]. These phenomena affected capture fishery productivity. An investigation conducted in Ghana found that fish species distribution and availability, such as tuna, were affected by climate change. Also, it had a great implication for fishery actors, especially small-scale fishers in many developing countries [29]. Similarly, Bah, et al. [30] summarized that increased water temperature, unpredicted rainfall, and increased winds have resulted in the threat of uncertainties and risk in capture fishing, thus declining fish catchability and income. Shaffril, Samah, and D'Silva [19] claimed that climate change has declined the fishing effort. The effort to capture fish in Malaysia declined by $90 \%$ in a month during the northeast monsoon. As a result, the fishers' catchability was significantly reduced. This statement was also in line with Roessig, Woodley, Cech, and Hansen [4], who confirmed the small-scale fishers' income was lower during the northeast monsoon than the normal season by about US $\$ 188$.

Furthermore, the changes in climatic conditions limit the small-scale fishers in conducting their fishing activity. For instance, the small boats used by fishermen restrict their fishing due to unstable climate conditions such as wind speed and wave level [31]. The decline in the capture fisheries' productivity becomes a big challenge for the small-scale fishers to achieve their livelihood needs. Ensuring adequate and effective adaptation strategies is the key success factor. Practices of adaptation can substantially minimize threats and the climate change effects [32]. According to FAO [14], adaptation to climate change can be planned or impromptu. In capturing fisheries, adaptation strategies include the fishing targets, and timing or shift of the fishing ground.

\subsubsection{Changing the Fishing Target}

Changes in the marine ecosystems' distribution and productivity have been attributed to climate change and its effects on the abundance and available target species [33]. In any fishing grounds, some species' stocks may decrease, while other species' stocks increase [34]. For example, Roessig, Woodley, Cech, and Hansen [4] claimed that skipjack tunas' catches 
were optimum in 20 to 29 degrees Celsius of seawater temperature. During that period, the pool and line gear were the most effective and sustainable to catch tunas. Nevertheless, increasing the seawater surface temperature reduces the skipjack tunas' abundance [35]. Likewise, boreal fish's productivity declined as an impact of global warming in the North Sea, while new hot-water species increased [36]. Dulvy et al. [37] discovered that the bottom temperature of the North Sea had risen by 1.6 degrees Celsius in 25 years. During this season, the entire demersal fish assemblage deepened by $3.6 \mathrm{~m}$. In Peru, during the El Nino event in 1997-1998, fishers previously fitted with gill nets and purse seine nets rapidly changed their fishing gear to trawl nets to catch the new species resource that had arisen in the northern part of Peru [26]. Therefore, to face the fish redistribution, small-scale fishers need to change their species targets. However, they are also required to change their fishing gear to catch these new species.

\subsubsection{Changing of Fishing Time and Location}

Significant changes in marine conditions have been strongly associated with global warming, and these ecosystems are extremely vulnerable to climate change. Changes in water temperature make the fish move to another place that is more suitable for them [38] and shift their distribution ranges [39]. These problems affect the abundance of fish in the fishing grounds. In south-eastern Australia, the abundance of new species was found because of long-term changes in abundance and distribution of fish [40]. Furthermore, Townhill et al. [41] also claimed that desirable fish species may become available in new fishing grounds due to climate phenomena. The problem will certainly impact fishing activities. One solution, therefore, is to change the fishing time and location.

\section{Material and Method}

\subsection{Data Collection}

This study was conducted in East Java, Indonesia, which has experienced the climate change phenomena to a large extent. A study conducted by Kusuma, et al. [42] claimed that the average sea surface temperature in East Java increased by 0.8 degrees Celsius from 2007 to 2016. Moreover, this province is predicted to face an increase in average annual temperature from 0.8 to $1.0^{\circ} \mathrm{C}$ between 2020 and 2050; hence, it is relevant to the latest climatic era of the twentieth century [43]. Two regencies were chosen in this research, i.e., Malang and Probolinggo (Figure 1), with the consideration that the two regencies have two main fishing ports in East Java, namely Sendang Biru (Malang) and Paiton (Probolinggo). Malang regency is located in the southern part of Java, representing East Java's southern coastal area. Geographically, Malang regency is located at $7.9797^{\circ} \mathrm{S}$ and $112.6304^{\circ} \mathrm{E}$. Meanwhile, Probolinggo regency is located in the north of East Java province. This location represents the northern coastal area of East Java and is located between $7^{\circ} 44^{\prime} 07^{\prime \prime} \mathrm{S}$ and $113^{\circ} 28^{\prime} 18^{\prime \prime}$ E (Figure 1).

Data were obtained from the fishers' household interviews conducted from November 2019 to December 2019. In this research, respondents were small-scale fishers who owned boats smaller or equal to five gross tonnages (GT). The respondents were determined by simple random sampling. The first stage of the sampling was listing the fishers in the two regencies to obtain the sampling frame. Secondly, the fishers' were sorted based on the requirements of this study, namely fishers who owned a boat smaller or equal to five gross tonnages and fishers who were engaged in Sendang Biru and Paiton fishing ports. After sorting the fishers based on the requirements, 297 fishers were listed and used as the research population. In the next stage, 170 were determined based on the Slovin measurement. Then, 85 fishers were taken randomly in every regency. The interviews were conducted face-to-face by using a structured questionnaire, which was developed after reviewing the relevant literature and interviewing key informants from the government, fisher communities, and the fishers themselves. To obtain the relevant data, the interview was conducted in the common language in the research location, which is Indonesian. 

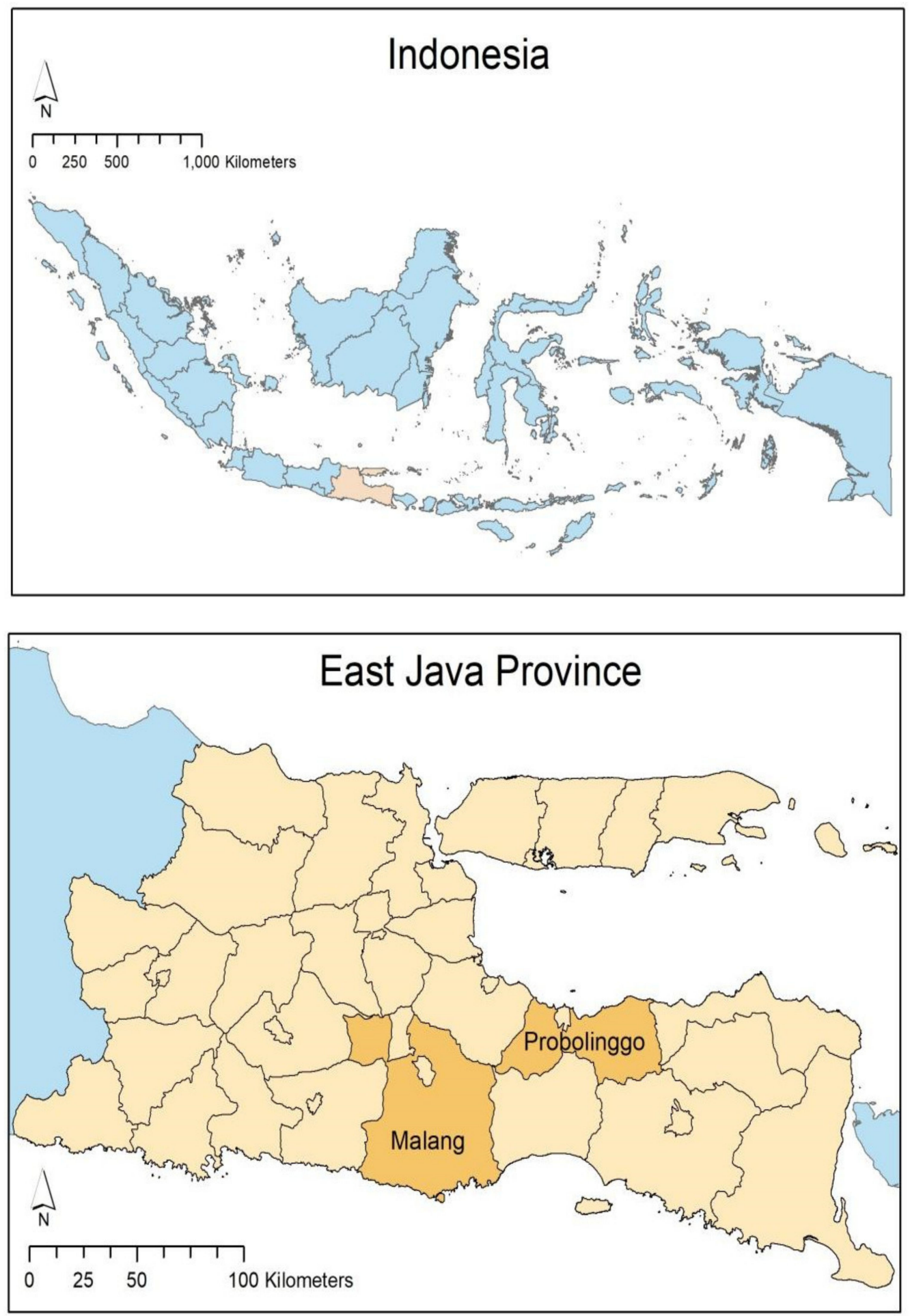

Figure 1. Location of the study area in East Java, Indonesia.

The interview started with an introductory question about climate change, "Have you ever heard of climate change?" If the respondent's answer was "no", the interviewer needed to explain climate change, however if the answer was "yes", the interviewer proceeded to the next questions. The interview was divided into five parts. Firstly, the respondent was asked about their socio-demographic profiles, such as education, age, and experience. Secondly, the interviewer asked about the fishing activities, including fishing gear, fishing tools, commuting time, and distance. Thirdly, the interviewer asked about the price input, the fish production, and the fish price. In the fourth part, the fishers were asked about 
climate change. The opening question in this part asked about the fisher's climate change perception to gauge the understanding of the issue. Then, they were asked about the adaptation strategies to climate change. The next part of the interview asked about social participation, including the involvement in the fishers' group or community, social activity, and access to climate information, as well as the financial capital such as savings and access to credit. Lastly, the interviewer asked about food consumption to construct the food consumption score (FCS).

\subsection{Measuring Income and Food Security}

Outcome variables used in this research were income and food security. Production, prices, and input were considered to measure the income at the household level specific to capture fisheries. Household food security status, the second outcome variable, was determined using the food consumption score (FCS). To construct the FCS, a survey was conducted among the fishers about the consumption frequency of each food group in a week. According to the World Food Program (WFP), food can be divided into eight groups and every group has a weight or score, respectively. The main staple group has two scores, the pulses group has three scores, the vegetable group has one score, the fruit group has one score, the meat and fish group have four scores, milk has four scores, sugar has 0.5 scores, and oil has 0.4 scores [44]. The consumption frequencies in a week are then quantified. Any frequency values over seven are capped at seven. This value is determined for each food group and is multiplied by the food group score. The sum of the score for the food groups is the FCS. FCS has been validated to be used in developing countries such as Indonesia, and it has been widely used by previous studies to measure the household food security status in this country, such as Hasanah, et al. [45]; Isaura, et al. [46]; Toiba, et al. [47].

\subsection{Empirical Framework}

This research models climate change adaptation strategies under the premise that fishers have a choice between adopting and not adopting adaptation strategies. This study applied a random utility approach to estimate fishers' decision to adopt the adaptation strategies. Based on this approach, the amount of utility gained by fishers by following adaptation strategies is unknown $[48,49]$. However, the fishers' decision to adopt the adaptation strategies if the utility is gained from adoption is higher than the utility of those who did not adopt any strategies. The derived utility of adopting the adaptation strategies can be modeled as a function of observable factors in the latent variable specification, and can be written as follows:

$$
A_{i}^{*}=X_{i} \alpha+u_{i} ; A_{i}^{*}=1 \text { if } A_{i}^{*}>0 \text { and } 0 \text { otherwise }
$$

where $A_{i}^{*}$ is a dummy variable that is equal to 1 if the fishers adopt the climate change adaptation strategies and 0 if otherwise. $\alpha$ is a vector of the variable to be assessed, and $u_{i}$ is the error term. The vector $X_{i}$ represents the fisher characteristic that affects the fishers decision to adopt climate change adaptation strategies.

Propensity-score matching (PSM) was applied to evaluate the impact of adaptation on fisheries' income and food security because the adaptation is a self-selection process in the observed and unobserved variables. PSM has been widely used in previous studies in evaluating the impact of adaptation strategies [32]. One of the reasons households adopted climate change adaptation can be related to income and food security. If we only compared the income and food security between adaptation and non-adaptation groups, the comparison results do not make sense because of the selection bias. PSM method aims to overcome selection bias by forming comparable households based on each household's characteristics. After similar groups are formed, a comparison was carried out to distinguish between the adaptation and non-adaptation groups. The first step of the PSM procedure was to measure each respondent's propensity score. This can be done 
by assessing the probability of the fisher adopting the adaptation strategies. In the PSM method, the probability is indented as propensity score, and can be formulated as follows:

$$
P\left(X_{i}\right)=\operatorname{Prob}\left(A_{i}=1 \mid X_{i}\right)
$$

where $P\left(X_{i}\right)$ is the propensity score which is assessed by the probit model that regresses the adaptation strategies on fisher's characteristic variables.

The second step was choosing a matching algorithm that is used to perform the matching process between covariates. Several matching algorithms have been introduced to match similar adaptation and non-adaptation groups. The nearest neighbor matching and kernel-based matching methods are commonly used [50]. The nearest neighbor approach compares each treated individual (adaptation) with the control individual (non-adaptation) with the closest propensity score. It is typically used as a substitute in the control units.

The next steps were measuring the differences of each pair of units matched and eventually obtaining the Average Treatment Effect on the Treated (ATT) as the average of all these differences. In a kernel-based approach, all treated participants are compared to a weighted average of all controls by using weights inversely proportional to the distance between the treated and control classes' propensity scores. This study used two matching methods, including the nearest neighbor matching. The third step was identifying overlap and common support. In this step, a few observations were excluded because there were differences in propensity scores (too high or too low). Then, a balance test was performed to see the average outcome of the adaptation and the non-adaptation. The difference in the outcome variable is made by discovering the average difference in both household groups, which is usually known as the average effect of treatment for the treated (ATT), which can be written as follows:

$$
\begin{aligned}
& A T T=E\left\{Y_{1 i}-Y_{1 i} A_{i}=1\right\}=E\left[E\left\{Y_{1 i}-Y_{1 i} A_{i}=1, p\left(X_{i}\right)\right\}\right] \\
& =E\left[E\left\{Y_{1 i} A_{i}=1, p\left(X_{i}\right)\right\}-E\left\{Y_{0 i}, A_{i}=0, p\left(X_{i}\right)\right\} A_{i}=1\right]
\end{aligned}
$$

where the outcome variable of adaptation fishers and non-adaptation fishers are represented as $Y_{1}$ and $Y_{0}$, respectively, and $i$ refers to fishers. Finally, to compute the ATT, this analysis employs a bootstrapped standard error that accounts for the discrepancy caused by the matching estimate.

\section{Result}

\subsection{Descriptive Statistics}

Definitions and descriptive statistics of variables in this study are presented in Table 1. In response to climate change, the fishers in the current study have undertaken several adaptation strategies, including changing the fishing target and shifting fishing time and location. In line with the definition of the variables in Table 1, about $54.1 \%$ of all fishers did not apply any adaptation strategies, and only $45.9 \%$ of the fishers applied them or at least applied one adaptation strategy. The average fishing gear owned by the fishers were six units, with the most common being gill net and hand line. The average fishing tools owned by the fishers were four units, with the boat average size being $4.171 \mathrm{GT}$. The fishing tools commonly used by the fishers were lamps to lure the fish at night, and this often significantly improved the catchment [51]. 
Table 1. Descriptive statistics of variables used in the study.

\begin{tabular}{|c|c|c|c|c|c|c|}
\hline Variable & Definition & Percentage & Mean & Std. Dev & Minimal & Maximal \\
\hline \multicolumn{7}{|l|}{ Treatment Variable } \\
\hline Adaptation & $\begin{array}{l}1 \text { if the fisher applied } \\
\text { adaptation (changing the } \\
\text { fishing gear, and change the } \\
\text { fishing time and location) } 0 \\
\text { otherwise }\end{array}$ & 45.900 & & 0.500 & 0.000 & 1.000 \\
\hline \multicolumn{7}{|l|}{ Control variables } \\
\hline Fishing gear & $\begin{array}{l}\text { Total fishing gear owned by } \\
\text { fisher (unit) }\end{array}$ & & 6.224 & 2.801 & 2.000 & 20.000 \\
\hline Fishing tool & $\begin{array}{l}\text { Total fishing tool owned by } \\
\text { fisher (unit) }\end{array}$ & & 4.006 & 2.740 & 0.000 & 10.000 \\
\hline Saving & Saving owned (US\$) & & 217.110 & 202.251 & 7.008 & 1100.213 \\
\hline Access to credit & $\begin{array}{c}\text { Dummy, } 1 \text { if fisher had access } \\
\text { to credit (micro finance, } \\
\text { cooperative, and bank); } 0 \\
\text { otherwise }\end{array}$ & 55.900 & & 0.498 & 0.000 & 1.000 \\
\hline Fisher group & $\begin{array}{c}\text { Dummy, } 1 \text { if fisher } \\
\text { participated in fisher group; } 0 \\
\text { otherwise }\end{array}$ & 50.000 & & 0.501 & 0.000 & 1.000 \\
\hline Climate information & $\begin{array}{c}\text { Dummy, } 1 \text { if fisher had climate } \\
\text { information access (wind } \\
\text { speed, wave level, } \\
\text { temperature, and rain } \\
\text { intensity); 0 otherwise }\end{array}$ & 49.400 & & 0.501 & 0.000 & 1.000 \\
\hline Social activity & $\begin{array}{c}\text { Dummy, } 1 \text { if fisher } \\
\text { participated in social activity } \\
\text { (cultural, and religion activity); } \\
0 \text { otherwise }\end{array}$ & 79.400 & & 0.406 & 0.000 & 1.000 \\
\hline Length of the trips & $\begin{array}{c}\text { Fisher time in fishing activity } \\
\text { (hours) }\end{array}$ & & 213.171 & 76.369 & 70.000 & 370.000 \\
\hline Distance trip & $\begin{array}{l}\text { Distance to the fishing ground } \\
\qquad(\mathrm{Km})\end{array}$ & & 6.734 & 3.376 & 1.000 & 20.000 \\
\hline Age & Age of Fisher (in years) & & 47.965 & 10.872 & 25.000 & 81.000 \\
\hline Education & $\begin{array}{l}\text { Fisher education level } \\
\text { (in years) }\end{array}$ & & 7.571 & 3.593 & 0.000 & 12.000 \\
\hline Experience & $\begin{array}{l}\text { Experience in fishing activities } \\
\text { (in years) }\end{array}$ & & 26.453 & 13.230 & 3.000 & 59.000 \\
\hline Household size & Total family member & & 3.459 & 0.986 & 1.000 & 6.000 \\
\hline Boat & $\begin{array}{l}\text { the size of the boat used by the } \\
\text { fisher (gross tonnage) }\end{array}$ & & 4.171 & 0.901 & 1.500 & 5.000 \\
\hline \multicolumn{7}{|l|}{ Outcome Variables } \\
\hline Income & $\begin{array}{l}\text { Fishers' income (US\$/Month) } \\
\text { Aggregates household-level }\end{array}$ & & 189.357 & 96.757 & 70.077 & 1149.267 \\
\hline $\begin{array}{l}\text { Food Consumption } \\
\text { Score }\end{array}$ & $\begin{array}{l}\text { data on the diversity and } \\
\text { frequency of food groups } \\
\text { consumed }\end{array}$ & & 32.876 & 2.443 & 23.000 & 39.000 \\
\hline
\end{tabular}

The average savings owned by fishers was about US\$217.110, and more than 50\% of the fishers had access to back credit. In terms of social engagement, about $50 \%$ of the respondents participated in the fishers' communities; however, less than 50\% had access to climate information. According to Owusu et al. [52], climate information was accessed through media, e.g., mobile, TV and radio, information centers, and government institutions. The climate information center provided by the ministry of marine and fisheries in the fishing port area was the fishers' primary access to climate information. Meanwhile, over $70 \%$ participated in social activities, including community service and cultural activity. For the fishing commutes, the fishers traveled for about $7.1 \mathrm{~h}$ per day, with an average of $213.171 \mathrm{~h}$ per month. The average distance to the fishing ground was 
about $6.734 \mathrm{~km}$. All the respondents in this research were male with an average age of 48 years old, and had experienced fishing activities for about 26 years. Most of the fishers' educations were elementary and junior high school, and the average household size was about three persons. Incomes and food consumption scores are the outcome variables. The average income earned by the fishers was about US $\$ 189.357$ per month. This value is lower than the income per capita in Indonesia. According to BPS (2020), Indonesia's income per capita in 2019 was US\$347.9 per month. Meanwhile, the FCS was 32.876, which is borderline [44].

The average differences in characteristics of fishers who adopted the adaptation strategies and who did not are presented in Table 2. It displays that 78 respondents adopted the strategies, and 92 respondents did not. The amount of fishing gear and the amount of savings owned by the fishers who have adopted the strategies was significantly higher than those who did not. Furthermore, the fishers who adopted the strategies were more likely to have access to credit, climate information, and social activities. It is implied that social capital has an important role in increasing the adaptive capacity of fishers. The commuting time was not significantly different between the two fisher groups. This means that the fishers applied a similar fishing pattern. However, the distance to the fishing ground was significantly different. The fishers who did not apply any adaptation strategies tended to have longer trip distances. The fishers who applied the adaptation strategies were younger and more educated than those who did not. The fishers who did not adopt adaptation strategies had a higher level of experience than those who did not adopt any adaptation strategies. The sizes of households were not statistically different between the two groups. However, the fishers who adopted adaptation strategies had larger boat sizes than those who did not. In terms of outcomes, there was a significant difference between the two groups. The fishers who applied adaptation strategies earned higher incomes and had better food security.

Table 2. Average difference of variable characteristics between adaptation and non-adaptation.

\begin{tabular}{|c|c|c|c|c|c|}
\hline \multirow{2}{*}{ Variable } & \multicolumn{2}{|c|}{ Adaptation $(n=78)$} & \multicolumn{2}{|c|}{ Non Adaptation $(n=92)$} & \multirow{2}{*}{$t$-Value } \\
\hline & Mean & Std. Dev. & Mean & Std. Dev. & \\
\hline Fishing gear (unit) & 7.385 & 3.063 & 5.239 & 2.119 & $5.372 * * *$ \\
\hline Fishing tool (unit) & 5.128 & 0.301 & 3.054 & 0.255 & $5.296^{* * *}$ \\
\hline Saving (US\$) & 320.054 & 218.962 & 129.831 & 136.433 & $6.903^{* * *}$ \\
\hline Access to credit (dummy) & 0.872 & 0.336 & 0.293 & 0.458 & $9.238^{* * *}$ \\
\hline Fisher group (dummy) & 0.833 & 0.375 & 0.217 & 0.415 & $10.079 * * *$ \\
\hline Climate information (dummy) & 0.782 & 0.416 & 0.250 & 0.435 & $8.107 * * *$ \\
\hline Social activity (dummy) & 0.923 & 0.268 & 0.685 & 0.467 & $3.982 * * *$ \\
\hline Length of the trips (hours) & 221.269 & 82.042 & 206.304 & 70.936 & $1.276 *$ \\
\hline Distance trip $(\mathrm{km})$ & 5.165 & 2.337 & 8.065 & 3.558 & $-6.156^{* * *}$ \\
\hline Age (years) & 46.167 & 10.326 & 49.489 & 11.143 & $-2.003^{* *}$ \\
\hline Education (years) & 9.808 & 2.634 & 5.674 & 3.190 & $9.110 * * *$ \\
\hline Experience (years) & 22.808 & 13.258 & 29.543 & 12.461 & $-3.410^{* * *}$ \\
\hline Household size (person) & 3.424 & 1.051 & 3.500 & 0.908 & 0.500 \\
\hline Boat size (gross tonnage) & 3.987 & 1.022 & 4.326 & 0.754 & $-2.482^{* * *}$ \\
\hline Income (US\$) & 225.451 & 53.126 & 158.755 & 113.731 & $4.756^{* * *}$ \\
\hline Food Consumption Score (FCS) & 33.628 & 2.380 & 32.239 & 2.322 & $3.842 * * *$ \\
\hline
\end{tabular}

Note: ${ }^{*}, * * * *$ denote significance on $10 \%, 5 \%$, and $1 \%$ respectively.

\subsection{Factors Affecting Fishers' Adaptation to Climate Change}

The probit model illustrates the influence of the socioeconomic variable on fishers' decision to apply adaptation strategies to climate change. Table 3 presents the associated probit estimates. Participation in the fishers' group was highly significant and positively related to adaptation strategies, followed by access to credit, education, and climate information. Meanwhile, the fishers' age had a negative and significant effect on adaptation strategies. 
Table 3. Parameter estimates from the probit model for estimating determinants of adaptation to climate change.

\begin{tabular}{ccccc}
\hline Variable & Coef. & Std. Err & z & $p>|\mathbf{z}|$ \\
\hline Fishing gear (unit) & -0.005 & 0.060 & -0.090 & 0.927 \\
Fishing tool (unit) & 0.063 & 0.055 & 1.150 & 0.250 \\
Saving (UDS) & $-2.04 \times 10^{-8}$ & $6.33 \times 10^{-8}$ & -0.320 & 0.747 \\
Access to credit (dummy) & 0.785 & 0.350 & 2.240 & $0.025^{* *}$ \\
Fisher group (dummy) & 0.814 & 0.338 & 2.410 & $0.016^{* *}$ \\
Climate information (dummy) & 0.665 & 0.333 & 2.000 & $0.046^{* *}$ \\
Social activity (dummy) & 0.351 & 0.437 & 0.800 & 0.422 \\
Length of the trips (hours) & 0.002 & 0.002 & -1.400 & 0.404 \\
Distance trip (km) & -0.075 & 0.054 & -2.430 & 0.0162 \\
Age (years) & -0.039 & 0.016 & 2.100 & $0.036^{* *}$ \\
Education (years) & 0.108 & 0.051 & 0.015 & 0.158 \\
Experience (years) & 0.021 & 0.146 & -1.250 & 0.388 \\
Household size (person) & 0.126 & 0.164 & -0.560 & 0.211 \\
Boat size (gross tonnage) & -0.205 & 1.388 & 170 & 0.574 \\
-cons & -0.781 & & 121.060 & 0.000 \\
Thumber of obs & & & 0.516 & \\
LR chi2(12) & & & & \\
Prob. > chi2 & & & & \\
\hline
\end{tabular}

Note: ${ }^{*}, * *$, denote significance on $10 \%, 5 \%$, and $1 \%$ respectively.

Fishers who had access to credit were more likely to apply the adaptation strategies. Access to credit is one of the financial capitals that can improve fishing in adapting to climate change. With limited financial capital, fishers may fail to meet the cost of adaptation strategies. Access to credit is a source of support for fishing activities. Being able to access it enabled fishers to easily purchase the necessary input [53,54]. Participating in fishers' groups made the fishers more likely to apply the adaptation strategies. A fishers' group is associated with comprehensive information about the fishing activities, including adaptation to climate change [55]. This is in line with the findings from the previous studies $[56,57]$. Furthermore, the fishers who had access to climate information were more likely to adopt adaptation strategies. Ouedraogo, et al. [58] claimed that climate information has positively contributed to adaptation strategies in fishing capture activities. The information convinces the fishers about the importance of mitigating climate change impacts by using adaptation strategies in their practices [59]. Climate information can also function as an early warning system that can minimize the capture fisheries' vulnerability to climate change [26]. Many studies also reported a strong positive effect between climate information and adaptation strategies [10,60-62].

Younger fishers had a higher probability of adapting to climate change. This finding implies that younger fishers were more likely to be adaptive than older fishers. Younger fishers were able to adapt to new circumstances and older fishers may find it hard to learn new strategies due to limited knowledge and energy [63]. This finding is not surprising because much of the literature is in line with these findings $[20,64,65]$. In regard to the level of education, more educated fishers were more likely to be adaptive than those who were less educated. Education had a significant influence on the preference of strategies for adaptation. Abu Samah, Shaffril, Hamzah, and Abu Samah [20] claimed that fishers with low literacy and education were not sensitive to climate change adaptation. Educated fishers are supposed to be more informed about climate change. According to Yegbemey et al. [66], the more educated they were, the more they are concerned about climate change and develop adaptation strategies.

\subsection{Impact of Adaptation Strategies on Income and Food Security}

The impact of adaptation strategies on the income and food consumption score (FCS) was assessed by using nearest neighbor matching (NNM) and kernel-based matching. These two methods were applied to compare the adaptation group of fishers to the non- 
adaptation group by focusing on the similar propensity score. In the propensity score matching procedures, the unmatched respondents were dropped from the matching. Therefore, the sample size was reduced in the matching analysis. The distribution of propensity scores is presented in Figure 2. The result shows the individual propensity scores between the adaptation and non-adaptation groups. The propensity score of the adaptation group is shown in the upper half of the graph. On the other hand, the propensity score of the non-adaptation group is shown in the bottom half of the graph.

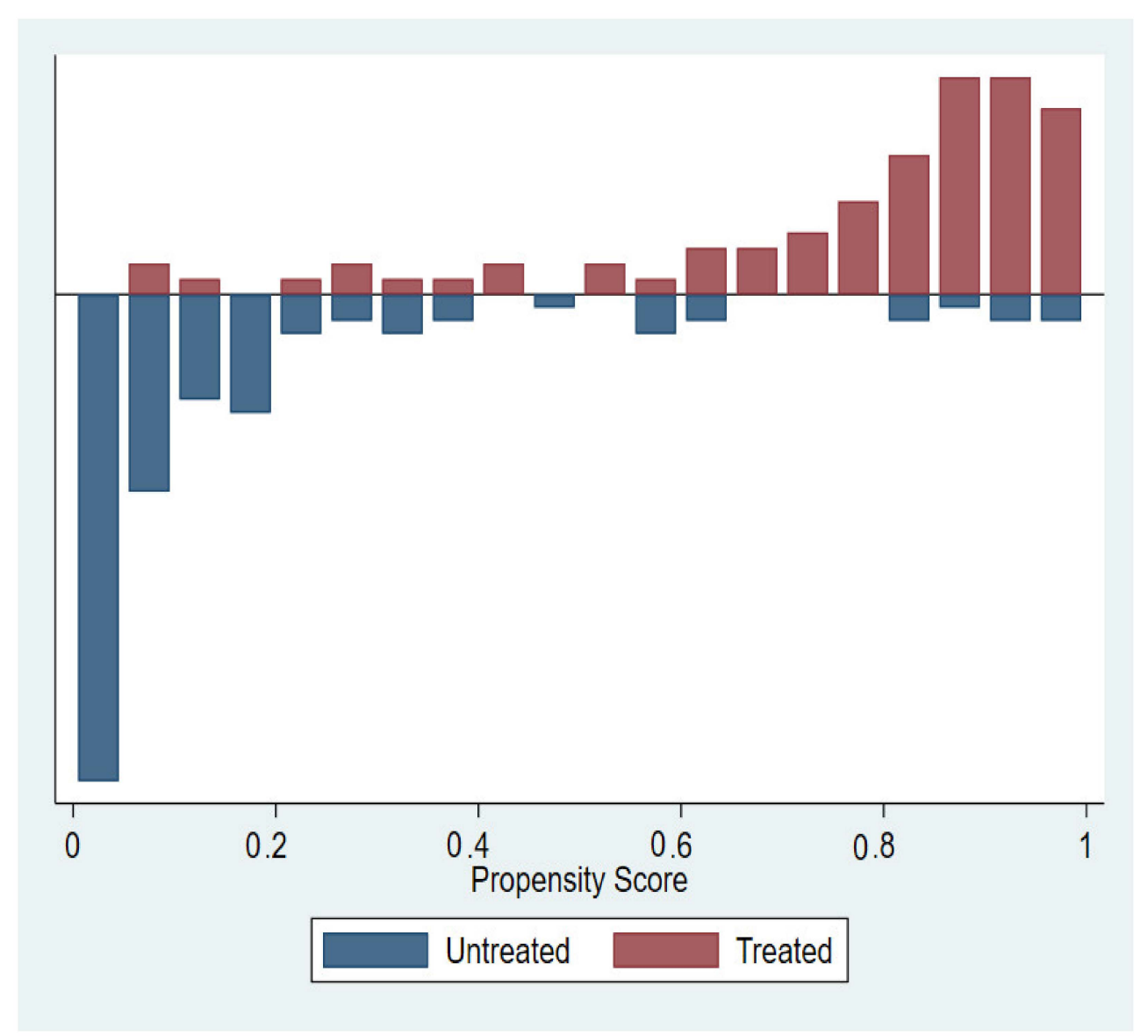

Figure 2. Distribution of propensity score estimation for adaptation and non-adaptation groups.

The impact of adaptation on income is presented in Table 4. The result shows that adaptation strategies have a positive and significant impact on the fishers' income. The NNM method shows that the causal impact of adaptation strategies on fishers' income was about US $\$ 45.270$. This value is the mean difference in household income in capture fisheries' activity between similar pairs of adaptation and non-adaptation groups. In terms of causal effects, the kernel-based matching method appears to be similar to the NNM method. The ATT value of kernel-based matching is about US\$39.594. The results of NNM and kernel-based matching imply that the fishers who applied the adaptation strategies earned an income of about US $\$ 45.270$ to US $\$ 39.594$ higher than those who did not apply adaptation strategies. Table 4 also presents the estimated effects of adaptation on food consumption score (FCS). The ATT value of NNM and kernel-based matching was about 1.745 and 1.524 , respectively, with significance levels at $1 \%$ and $5 \%$. This result reveals that adaptation strategies tend to significantly and positively impact the FCS. The ATT's value illustrates that the fishers who applied adaptation strategies produced higher FCS at about 1.518 to 1.745 than those who did not. 
Table 4. The impact of climate change adaptation strategies on income and food security.

\begin{tabular}{ccccccc}
\hline Matching Algorithm & Outcome & Treated & Control & ATT & Std. Err & $t$-Value \\
\hline \multirow{2}{*}{ Nearest neighbor Matching } & Income & 78 & 17 & 45.27 & 8.479 & $5.353^{* * *}$ \\
& FCS & 78 & 17 & 2.974 & 0.381 & $7.811^{* * *}$ \\
Kernel-based matching & Income & 78 & 44 & 39.594 & 25.788 & $1.536^{* *}$ \\
& FCS & 78 & 44 & 2.698 & 0.692 & $3.897^{* * *}$ \\
\hline
\end{tabular}

Note: ${ }^{* *}, * * *$ denote significance on $10 \%, 5 \%$, and $1 \%$ respectively.

\section{Discussion}

This section discusses the findings on the impact of climate change adaptation strategy on income and food security among small-scale fishers. Two practices of adaptation strategies were implemented by small-scale fishers in East Java, Indonesia, namely changing the fishing gear and changing fishing time and location. This study revealed that climate change adaptation strategies have an essential role to improve the income of small-scale fishers. Adaptation strategies could increase fishers' income by providing higher fish catchability. The change in fish distribution and fish availability due to the climate change impact on the fish availability. Fishers need to adjust their fishing gear, depending on the abundance of the fish species in the location (i.e., demersal or pelagic fish). For instance, the common fishing gear that has been used by the small-scale fishers in East Java is gillnet and trap to catch the demersal fish such as grouper, snapper, and golden threadfin bream. However, the decline in demersal fish species productivity due to changes in ocean water conditions (chemical, physical, and biological conditions) affected the fisheries' catchability. Therefore, they changed their fishing gear to catch pelagic species that are more abundant, such as mackerel tuna, skipjack tuna, and chub mackerels. On the other hand, the distribution of fish due to climate change also affected the availability of desirable fish species with the highest values in another fishing area. Therefore, fishers require adjusting their fishing location. As a result, these adaptation strategies can increase catchability, which impacts their income. These results are generally in line with the findings by Abid, Schneider, and Scheffran [48], who estimated the impact of climate change adaptation strategy on food productivity and income in Pakistan. The findings indicated that adaptation strategies have a positive and significant impact on food productivity and income. Furthermore, this finding also supports the findings by Dey, Gosh, Valmonte-Santos, Rosegrant, and Chen [67], who used the projection model to estimate the economic impact of adaptation strategies in Solomon Island. They argued that the adaptation to climate change improved fisheries' production, which subsequently increased the fishers' income. A study in the Arctic Ocean shows that the fishing cost was predicted to increase by $39 \%$ or US $\$ 1.2$, thereby affecting fishers' income [68]. Likewise, Lam, Cheung, and Sumaila [69] predicted that the fisheries' revenue could decrease by $35 \%$ as an impact of climate change. Therefore, the strategy to quickly adapt to climate change is an essential factor determining the outcomes of capture fisheries, especially the small-scale fishers' income [26]. The result of this study can be the solution to increase the overall revenue of the fisheries sector.

Furthermore, adaptation strategies also have an important role in fishers' FCS. Based on the findings of this research, fishers who applied adaptation have higher FCS than those who did not apply the adaptation strategies. FCS is a measurement for household food security status developed by the world food program in 1996. FCS explains the household food security status as the proxy of the food quantity that is consumed. Moreover, FCS takes into account the relative nutritional significance of various food categories, not simply dietary diversity and food frequency. Higher FCS lead to better food security status. Therefore, the positive impact of adaptation strategies on FCS also captures better fishers' food security. This finding can be explained by two possibilities. First, adaptation strategies improve fishers' purchasing power of food products by increasing their revenue. Second, it increases the fishers' consumption of fish by providing more fish catchability. This is consistent with the previous research conducted by Ali and Erenstein [32], who estimated the impact of adaptation practices on household food security. They found 
that adaptation practices are positively associated with household food security levels. A similar study employed by Amare and Simane [70] found that farmers who adopted the adaptation strategy had higher food calorie intake than those who did not. Overall, this study confirms and qualifies the empirical evidence that climate change adaptation strategies provide substantial benefits to fishers through improved income and household food security among small-scale fishers.

One of the limitations of this study is that it only used observable variables, such as socio-demographic characteristics and fisheries-related factors, to understand factors affecting the fishers' decision to adopt the adaptation strategies, whereas unobservable variables, for instance, the characteristics of fishers' personalities such as perseverance, talents, and perceptions of fishers were not included. In future studies, this should be taken into consideration.

\section{Conclusions}

This study estimated the factors affecting the adaptation strategies to climate change and the associated impact on households' income and food security in East Java, Indonesia. Fishers in East Java applied some adaptation strategies, including technology adoption, changing their fishing gear, and shifting fishing time and location. This study found that $48.2 \%$ of the fishers applied adaptation strategies. Probit regression analysis was used to evaluate the determinants of adaptation strategies on climate change, and propensity score matching (PSM) was applied to estimate the impact of adaptation strategies on income and household food security. The food consumption score was used to determine food security. An interesting finding from probit model estimation was that the fishing gear, fishing tools, and savings as well as the fishers' assets had no significant influence on adaptation strategies. However, access to credit and social capital, including access to fishers groups and climate information, had a positive and significant effect on the adaptation strategies. This finding can be explained by two possibilities: (1) financial capital can provide support for the fishers to apply the adaptation strategy, such as buying more gear; (2) social capital can provide information resources such as fish abundance, climate prediction, and potential new fishing grounds.

Based on the findings of this research, it was shown that climate change adaptation strategies helped small-scale fishers improve their income and food security in dealing with the negative impact of climate change. Therefore, the study suggests that small-scale fishers should implement the climate change adaptation strategy continuously in their fishing activity to maintain and improve their income and food security. Furthermore, this study also suggests for policymakers to promote and improve the small-scale fishers' adaptation capacity in three ways. First, improving the availability of access to credit to support fishers' financial needed to employ the adaptation strategies. Second, providing climate information access such as wind speed, wave level, temperature, and rain intensity to improve fishers' awareness about climate change. Third, establishing fisher groups to increase fishers' capacity to share and promote climate change adaptation strategies.

This study employed two outcome variables to estimate the impact of adaptation strategies, including income and food security. Future research may be improved by including other outcome variables such as poverty, technical efficiency, and fishing performance. Investigation into the impact of adaptation strategies based on other outcome variables will support the finding of this study.

Author Contributions: Conceptualizations, methodology and validation, M.S.R., W.-C.H. and H.T.; investigation, resources, data curation M.S.R. and H.T. formal analysis, writing-original draft preparation, M.S.R. writing-review and editing, M.S.R. and W.-C.H.; supervision W.-C.H. All authors have read and agreed to the published version of the manuscript.

Funding: This research received no external funding.

Institutional Review Board Statement: Not applicable.

Informed Consent Statement: Not applicable. 
Data Availability Statement: The data presented in this study are available on request from the corresponding author. The data are not publicly available due to ethical reasons.

Acknowledgments: The authors are grateful to reviewers for their valuation contributions to enhance the presentation of the paper.

Conflicts of Interest: The authors declare no conflict of interest.

\section{References}

1. Aldrian, E.; Djamil, Y.S. Spatio-temporal climatic change of rainfall in East Java Indonesia. Int. J. Climatol. A J. R. Meteorol. Soc. 2008, 28, 435-448. [CrossRef]

2. Avia, L.Q. Change in rainfall per-decades over Java Island, Indonesia. In Proceedings of the IOP Conference Series: Earth and Environmental Science, Medan, Indonesia, 18-19 October 2019; p. 012037.

3. Muskananfola, M.R.; Febrianto, S. Spatio-temporal analysis of shoreline change along the coast of Sayung Demak, Indonesia using Digital Shoreline Analysis System. Reg. Stud. Mar. Sci. 2020, 34, 101060. [CrossRef]

4. Roessig, J.M.; Woodley, C.M.; Cech, J.J.; Hansen, L.J. Effects of global climate change on marine and estuarine fishes and fisheries. Rev. Fish Biol. Fish. 2004, 14, 251-275. [CrossRef]

5. Bertrand, A.; Lengaigne, M.; Takahashi, K.; Avadí, A.; Poulain, F.; Harrod, C. El Niño Southern Oscillation (ENSO) effects on fisheries and aquaculture. FAO Fish. Aquac. Tech. Pap. 2020. [CrossRef]

6. Grafton, R.Q. Adaptation to climate change in marine capture fisheries. Mar. Policy 2010, 34, 606-615. [CrossRef]

7. Kleisner, K.M.; Fogarty, M.J.; McGee, S.; Hare, J.A.; Moret, S.; Perretti, C.T.; Saba, V.S. Marine species distribution shifts on the US Northeast Continental Shelf under continued ocean warming. Prog. Oceanogr. 2017, 153, 24-36. [CrossRef]

8. Asante, F.A.; Amuakwa-Mensah, F. Climate change and variability in Ghana: Stocktaking. Climate 2015, 3, 78-99. [CrossRef]

9. Iwasaki, S.; Razafindrabe, B.H.N.; Shaw, R. Fishery livelihoods and adaptation to climate change: A case study of Chilika lagoon, India. Mitig. Adapt. Strateg. Glob. Chang. 2009, 14, 339-355. [CrossRef]

10. Oduniyi, O.S.; Tekana, S.S. Adoption of agroforestry practices and climate change mitigation strategies in North West province of South Africa. Int. J. Clim. Chang. Strateg. Manag. 2019. [CrossRef]

11. Daw, T.; Adger, W.N.; Brown, K.; Badjeck, M.-C. Climate change and capture fisheries: Potential impacts, adaptation and mitigation. World Fish 2009. Available online: https:/ / hdl.handle.net/20.500.12348/1339 (accessed on 15 July 2021).

12. Colgan, C.S.; Merrill, S.B. The effects of climate change on economic activity in Maine: Coastal York County case study. Maine Policy Rev. 2008, 17, 66-79.

13. Mabe, F.N.; Asase, A. Climate change adaptation strategies and fish catchability: The case of inland artisanal fishers along the Volta Basin in Ghana. Fish. Res. 2020, 230, 105675. [CrossRef]

14. FAO. The State of World Fisheries and Aquaculture: Contributing to Food Security and Nutrition for All; FAO: Rome, Italy, 2016.

15. Fiorella, K.J.; Hickey, M.D.; Salmen, C.R.; Nagata, J.M.; Mattah, B.; Magerenge, R.; Cohen, C.R.; Bukusi, E.A.; Brashares, J.S.; Fernald, L.H. Fishing for food? Analyzing links between fishing livelihoods and food security around Lake Victoria, Kenya. Food Secur. 2014, 6, 851-860. [CrossRef]

16. Taylor, S.F.; Roberts, M.J.; Milligan, B.; Ncwadi, R. Measurement and implications of marine food security in the Western Indian Ocean: An impending crisis? Food Secur. 2019, 11, 1395-1415. [CrossRef]

17. Bell, J.D.; Cisneros-Montemayor, A.; Hanich, Q.; Johnson, J.E.; Lehodey, P.; Moore, B.R.; Pratchett, M.S.; Reygondeau, G.; Senina, I.; Virdin, J. Adaptations to maintain the contributions of small-scale fisheries to food security in the Pacific Islands. Mar. Policy 2018, 88, 303-314. [CrossRef]

18. Bryan, E.; Deressa, T.T.; Gbetibouo, G.A.; Ringler, C. Adaptation to climate change in Ethiopia and South Africa: Options and constraints. Environ. Sci. Policy 2009, 12, 413-426. [CrossRef]

19. Shaffril, H.A.M.; Samah, A.A.; D'Silva, J.L. Adapting towards climate change impacts: Strategies for small-scale fishermen in Malaysia. Mar. Policy 2017, 81, 196-201. [CrossRef]

20. Abu Samah, A.; Shaffril, H.A.M.; Hamzah, A.; Abu Samah, B. Factors affecting small-scale fishermen's adaptation toward the impacts of climate change: Reflections from Malaysian fishers. SAGE Open 2019, 9, 1-11. [CrossRef]

21. Sereenonchai, S.; Arunrat, N. Fishers' Decisions to Adopt Adaptation Strategies and Expectations for Their Children to Pursue the Same Profession in Chumphon Province, Thailand. Climate 2019, 7, 34. [CrossRef]

22. Lowe, B.S.; Jacobson, S.K.; Anold, H.; Mbonde, A.S.; O'Reilly, C.M. Adapting to change in inland fisheries: Analysis from Lake Tanganyika, East Africa. Reg. Environ. Chang. 2019, 19, 1765-1776. [CrossRef]

23. Le Dang, H.; Li, E.; Nuberg, I.; Bruwer, J. Understanding farmers' adaptation intention to climate change: A structural equa-tion modelling study in the Mekong Delta, Vietnam. Environ. Sci. Policy 2014, 41, 11-22. [CrossRef]

24. Edwards, C.B.; Friedlander, A.; Green, A.; Hardt, M.; Sala, E.; Sweatman, H.; Williams, I.; Zgliczynski, B.; Sandin, S.; Smith, J. Global assessment of the status of coral reef herbivorous fishes: Evidence for fishing effects. Proc. R. Soc. B Biol. Sci. 2014, 281, 20131835. [CrossRef]

25. Hoegh-Guldberg, O.; Bruno, J.F. The impact of climate change on the world's marine ecosystems. Science 2010, 328, 1523-1528. [CrossRef] [PubMed] 
26. Badjeck, M.-C.; Allison, E.H.; Halls, A.S.; Dulvy, N.K. Impacts of climate variability and change on fishery-based livelihoods. Mar. Policy 2010, 34, 375-383. [CrossRef]

27. Muringai, R.T.; Naidoo, D.; Mafongoya, P.; Lottering, S. The impacts of climate change on the livelihood and food security of small-scale fishers in Lake Kariba, Zimbabwe. J. Asian Afr. Stud. 2020, 55, 298-313. [CrossRef]

28. Rizal, A.; Anna, Z. Climate change and its possible food security implications toward Indonesian marine and fisheries. World News Nat. Sci. Int. Sientific J. 2019, 22. Available online: https://agro.icm.edu.pl/agro/element/bwmeta1.element.agro-e303250ff51b-47b0-b935-b8917d2aa8dc (accessed on 13 July 2021).

29. Barange, M.; Bahri, T.; Beveridge, M.C.; Cochrane, K.L.; Funge-Smith, S.; Poulain, F. Impacts of Climate Change on Fisheries and Aquaculture: Synthesis of Currrent Knowledge, Adaptation and Mitigation Options; FAO: Rome, Italy, 2018.

30. Bah, O.A.; Kone, T.; Yaffa, S.; Sawaneh, M.; Kone, D. Fishers' perceptions of climate change on freshwater fisheries and the role of these systems in their adaptation strategy in Central River Region of the Gambia. Int. J. Agric. Environ. Res. 2018, 4, 321-340.

31. Colgan, C.; Merrill, S.; Rubin, J. Energy Efficiency, Business Competitiveness, and Untapped Potential in Maine. Energy \& the Environment 2008. Available online: https:/ / digitalmaine.com/energy_docs/27/ (accessed on 13 July 2021).

32. Ali, A.; Erenstein, O. Assessing farmer use of climate change adaptation practices and impacts on food security and poverty in Pakistan. Clim. Risk Manag. 2017, 16, 183-194. [CrossRef]

33. Belhabib, D.; Lam, V.W.; Cheung, W.W. Overview of West African fisheries under climate change: Impacts, vulnerabilities and adaptive responses of the artisanal and industrial sectors. Mar. Policy 2016, 71, 15-28. [CrossRef]

34. McIlgorm, A.; Hanna, S.; Knapp, G.; Le Floc'H, P.; Millerd, F.; Pan, M. How will climate change alter fishery governance? Insights from seven international case studies. Mar. Policy 2010, 34, 170-177. [CrossRef]

35. Andrade, $\mathrm{H}$. The relationship between the skipjack tuna (Katsuwonus pelamis) fishery and seasonal temperature variability in the south-western Atlantic. Fish. Oceanogr. 2003, 12, 10-18. [CrossRef]

36. Stenevik, E.K.; Sundby, S. Impacts of climate change on commercial fish stocks in Norwegian waters. Mar. Policy 2007, 31, 19-31. [CrossRef]

37. Dulvy, N.; Chassot, E.; Hyemans, J.; Hyde, K.; Pauly, D. Climate change, ecosystem variability and fisheries productivity. Remote Sens. Fish. Aquac. Soc. Benefits IOCCG Rep. 2009, 8, 11-28.

38. Murawski, S. Climate change and marine fish distributions: Forecasting from historical analogy. Trans. Am. Fish. Soc. 1993, 122, 647-658. [CrossRef]

39. Comte, L.; Buisson, L.; Daufresne, M.; Grenouillet, G. Climate-induced changes in the distribution of freshwater fish: Observed and predicted trends. Freshw. Biol. 2013, 58, 625-639. [CrossRef]

40. Last, P.R.; White, W.T.; Gledhill, D.C.; Hobday, A.J.; Brown, R.; Edgar, G.J.; Pecl, G. Long-term shifts in abundance and distribution of a temperate fish fauna: A response to climate change and fishing practices. Glob. Ecol. Biogeogr. 2011, 20, 58-72. [CrossRef]

41. Townhill, B.L.; Radford, Z.; Pecl, G.; van Putten, I.; Pinnegar, J.K.; Hyder, K. Marine recreational fishing and the implications of climate change. Fish Fish. 2019, 20, 977-992. [CrossRef]

42. Kusuma, D.; Murdimanto, A.; Aden, L.; Sukresno, B.; Jatisworo, D.; Hanintyo, R. Sea surface temperature dynamics in Indonesia. In Proceedings of the IOP Conference Series: Earth and Environmental Science, Yogyakarta, Indonesia, 27-28 September 2017; p. 012038.

43. Sriyanti, M.G. Indonesia Climate Change Sectoral Roadmap-ICCSR; BAPPENAS: Jakarta, Indonesia, 2010.

44. WFP. Food Consumption Analysis: Calculation and Use of the Food Consumption Score in Food Security Analysis; WFP: Rome, Italy, 2008.

45. Hasanah, A.; Mendolia, S.; Yerokhin, O. Labour migration, food expenditure, and household food security in eastern indonesia. Econ. Rec. 2017, 93, 122-143. [CrossRef]

46. Isaura, E.R.; Chen, Y.-C.; Yang, S.-H. Pathways from food consumption score to cardiovascular disease: A seven-year follow-up study of indonesian adults. Int. J. Environ. Res. Public Health 2018, 15, 1567. [CrossRef]

47. Toiba, H.; Nugroho, T.W.; Retnoningsih, D.; Rahman, M.S. Food system transformation and its impact on smallholder farmers' income and food security in Indonesia. Cogent Econ. Financ. 2020, 8, 1854412. [CrossRef]

48. Abid, M.; Schneider, U.A.; Scheffran, J. Adaptation to climate change and its impacts on food productivity and crop income: Perspectives of farmers in rural Pakistan. J. Rural Stud. 2016, 47, 254-266. [CrossRef]

49. Seo, S.N. An analysis of public adaptation to climate change using agricultural water schemes in South America. Ecol. Econ. 2011, 70, 825-834. [CrossRef]

50. Becerril, J.; Abdulai, A. The impact of improved maize varieties on poverty in Mexico: A propensity score-matching approach. World Dev. 2010, 38, 1024-1035. [CrossRef]

51. Yamashita, Y.; Matsushita, Y.; Azuno, T. Catch performance of coastal squid jigging boats using LED panels in combination with metal halide lamps. Fish. Res. 2012, 113, 182-189. [CrossRef]

52. Owusu, V.; Ma, W.; Renwick, A.; Emuah, D. Does the use of climate information contribute to climate change adaptation? Evidence from Ghana. Clim. Dev. 2020, 1-14. [CrossRef]

53. Fosu-Mensah, B.Y.; Vlek, P.L.; MacCarthy, D.S. Farmers' perception and adaptation to climate change: A case study of Sekyedumase district in Ghana. Environ. Dev. Sustain. 2012, 14, 495-505. [CrossRef]

54. Mulwa, C.; Marenya, P.; Kassie, M. Response to climate risks among smallholder farmers in Malawi: A multivariate probit assessment of the role of information, household demographics, and farm characteristics. Clim. Risk Manag. 2017, 16, $208-221$. [CrossRef] 
55. Arbuckle, J.G.; Prokopy, L.S.; Haigh, T.; Hobbs, J.; Knoot, T.; Knutson, C.; Loy, A.; Mase, A.S.; McGuire, J.; Morton, L.W. Climate change beliefs, concerns, and attitudes toward adaptation and mitigation among farmers in the Midwestern United States. Clim. Chang. 2013, 117, 943-950. [CrossRef]

56. Gc, A.; Yeo, J.-H. Perception to Adaptation of Climate Change in Nepal: An Empirical Analysis Using Multivariate Probit Model. Science 2020, 2, 87. [CrossRef]

57. Piya, L.; Maharjan, K.L.; Joshi, N.P. Determinants of adaptation practices to climate change by Chepang households in the rural Mid-Hills of Nepal. Reg. Environ. Chang. 2013, 13, 437-447. [CrossRef]

58. Ouedraogo, I.; Diouf, N.S.; Ouédraogo, M.; Ndiaye, O.; Zougmoré, R.B. Closing the gap between climate information producers and users: Assessment of needs and uptake in Senegal. Climate 2018, 6, 13. [CrossRef]

59. Zougmoré, R.; Partey, S.; Ouédraogo, M.; Omitoyin, B.; Thomas, T.; Ayantunde, A.; Ericksen, P.; Said, M.; Jalloh, A. Toward climate-smart agriculture in West Africa: A review of climate change impacts, adaptation strategies and policy developments for the livestock, fishery and crop production sectors. Agric. Food Secur. 2016, 5, 26. [CrossRef]

60. Asayehegn, K. Farmers' perception on climate change adaptation strategies: A case study from the irrigation schemes of Central Tigray Regional State, Ethiopia. Erud. J. Microbiol. Biodivers. 2012, 1, 1-6.

61. Deressa, T.T.; Hassan, R.M.; Ringler, C. Perception of and adaptation to climate change by farmers in the Nile basin of Ethiopia. J. Agric. Sci. 2011, 149, 23-31. [CrossRef]

62. Di Falco, S.; Veronesi, M.; Yesuf, M. Does adaptation to climate change provide food security? A micro-perspective from Ethiopia. Am. J. Agric. Econ. 2011, 93, 829-846. [CrossRef]

63. Coulthard, S. Adapting to environmental change in artisanal fisheries-Insights from a South Indian Lagoon. Global Environ. Chang. 2008, 18, 479-489. [CrossRef]

64. Khanal, U.; Wilson, C.; Hoang, V.-N.; Lee, B. Farmers' adaptation to climate change, its determinants and impacts on rice yield in Nepal. Ecol. Econ. 2018, 144, 139-147. [CrossRef]

65. Uddin, M.N.; Bokelmann, W.; Entsminger, J.S. Factors affecting farmers' adaptation strategies to environmental degradation and climate change effects: A farm level study in Bangladesh. Climate 2014, 2, 223-241. [CrossRef]

66. Yegbemey, R.N.; Yabi, J.A.; Tovignan, S.D.; Gantoli, G.; Kokoye, S.E.H. Farmers' decisions to adapt to climate change under various property rights: A case study of maize farming in northern Benin (West Africa). Land Use Policy 2013, 34, 168-175. [CrossRef]

67. Dey, M.M.; Gosh, K.; Valmonte-Santos, R.; Rosegrant, M.W.; Chen, O.L. Economic impact of climate change and climate change adaptation strategies for fisheries sector in Solomon Islands: Implication for food security. Mar. Policy 2016, 67, 171-178. [CrossRef]

68. Lam, V.W.; Cheung, W.W.; Reygondeau, G.; Sumaila, U.R. Projected change in global fisheries revenues under climate change. Sci. Rep. 2016, 6, 32607. [CrossRef] [PubMed]

69. Lam, V.W.; Cheung, W.W.; Sumaila, U.R. Marine capture fisheries in the Arctic: Winners or losers under climate change and ocean acidification? Fish Fish. 2016, 17, 335-357. [CrossRef]

70. Amare, A.; Simane, B. Does adaptation to climate change and variability provide household food security? Evidence from Muger sub-basin of the upper Blue-Nile, Ethiopia. Ecol. Process. 2018, 7, 13. [CrossRef] 